\title{
Effect of Mulching on Growth, Yield and Quality in Different Varieties of Summer Squash (Cucurbita pepo L.)
}

\author{
Dinesh Kumar and Rishu Sharma* \\ Department of Horticulture, School of Agriculture, Lovely Professional University, \\ Phagwara-144401, India \\ *Corresponding author
}

\section{A B S T R A C T}

\begin{tabular}{|l|}
\hline K e y w or d s \\
$\begin{array}{l}\text { Mulching, Growth, Yield } \\
\text { and Quality, Summer } \\
\text { Squash (Cucurbita pepo } \\
\text { L.) }\end{array}$ \\
\hline Article Info \\
\hline $\begin{array}{l}\text { Accepted: } \\
\text { 20 May 2018 } \\
\text { Available Online: } \\
\text { 10 June 2018 }\end{array}$ \\
\hline
\end{tabular}

Keywords

\section{Introduction}

Summer Squash (Cucurbita pepo L.) locally known as 'chappankaddoo' or 'valyatikaddoo' belongs to family cucurbitaceae is a native of Mexico and US. In India, Uttar Pradesh, Punjab and Haryana are the states where summer squash is considered among commonly consumed vegetable crops (Dhaliwal, 2012) with cultivation limits extending to Himachal Pradesh, Jammu and Kashmir and West Bengal. It is tender, annual, warm season vegetable crop that is harvested when fruits are immature (Sarhan et al., 2011) and contains carbohydrates, fibre, potassium, vitamin $B$ and vitamin $C$ that makes it higher in food value.
India share $14.78 \%$ production of squashes, pumpkins and gourds to worlds total production and stands at second position after China (22.83\%) (Anonymous, 2016).

Despite having appreciable production, productivity is very low in India which is a major concern in commercial cultivation of summer squash and the main factors contributing towards low productivity are weeds infestation, insects, pests and moisture stress. To combat all these problems in ecofriendly manner, mulching offers rewarding possibilities as use of intensive chemical measures leads to disturbance of ecological balance. Covering of soil with different mulch materials is an efficient method for soil and 
water conservation along with weed management (Bobby et al., 2017).

Plastic mulches are adopted on large scale in commercial vegetable production due to their large scale effects in gaining higher yield with better quality which might be due to decreased water evaporation, increased soil temperatures, less weed infestation (Coolong, 2010 and Gordon et al., 2008). Black plastic mulch is effective in increasing soil temperature (Mahadeen, 2014) and thereby improved the yield of summer squash by $74 \%$ over control (Bhatt et al., 2011) and transparent mulch helps in soil solarisation by increasing soil temperature that lead to yield gain of $25-28 \%$ in melon crop over control (Patil et al., 2013; Ekinci and Dursun, 2009). Sunlight can pass through the transparent mulch so weeds can grow under them and need to be controlled by spraying suitable herbicide before applying mulching (Anonymous, 2011). On the other hand, organic mulches when applied to soil in thick layer increase the moisture content and reduce the weed population but when it is used in vegetable crops during warm season, it shows the adverse effects on growth and yield (Coolong, 2012). So, pertaining to the need of popularizing the summer squash cultivation due to its better nutrient composition and important vegetable source, present investigations were planned and carried out with the objectives of evaluating the impact of different mulch materials on growth and yield of summer squash and to assess the varietal performance under different mulch regimes.

\section{Materials and Methods}

The experiment conducted during March June, 2017 at Agriculture Experimental Farm, Lovely Professional University, Phagwara, Punjab which geographically lies at latitude of $31.25^{\circ} \mathrm{N}$ and longitude of $75.70^{\circ} \mathrm{E}, 234 \mathrm{~m}$ above mean sea level. The experiment consisted of five mulch treatments viz., black plastic mulch $\left(\mathrm{M}_{1}\right)$, blue plastic mulch $\left(\mathrm{M}_{2}\right)$, rice straw mulch $\left(\mathrm{M}_{3}\right)$, transparent mulch $\left(\mathrm{M}_{4}\right)$ and control $\left(\mathrm{M}_{5}\right)$ and four varieties viz., Arpit $\left(V_{1}\right)$, Surya $\left(V_{2}\right)$, Pratap $\left(V_{3}\right)$ and Desi $\left(V_{4}\right)$, making the total of twenty treatment combinations. The experiment was conducted in split plot design where mulch materials were assisted in main plots, whilethe varieties were allocated in sub plots. The 20 treatment combinations were replicated thrice making the total of 60 plots with plot size of $3 \mathrm{~m} \mathrm{X} 1$ $\mathrm{m}$. The seeds were sown on $23^{\text {rd }}$ march, 2017 at spacing of $90 \mathrm{~cm} \mathrm{X} 60 \mathrm{~cm}$ following the recommended cultural practices of Punjab Agriculture University, Ludhiana. Observations were recorded for various growth, yield and quality parameters and subjected to analysis of variance (ANOVA) using split plot design as described by Gomez and Gomez (1984) keeping mulch materials as main plot and varieties as sub-plotusing analysis software, OPSTAT.

\section{Results and Discussion}

The findings of the present study indicated that different types of mulching materials had significant results on the vegetative growth parameters of summer squash viz., emergence percentage, plant height and number of leaves per plant. Among different mulch treatments, $\mathrm{M}_{4}$ (Transparent Mulch) resulted in maximum emergence $(83.33 \%)$, While the plant height $(138.22 \mathrm{~cm})$ and number of leaves per plant (100.42) were recorded highest in $\mathrm{M}_{1}$ (Black Plastic Mulch). All the growth parameters are superior under black plastic mulch except emergence percentage that is highest under $\mathrm{M}_{4}$ (Transparent Mulch) but found to be statistically at par with $\mathrm{M}_{1}$ (Black Plastic Mulch) (79.12\%) and $\mathrm{M}_{2}$ (Blue Plastic Mulch) $(72.22 \%)$, whereas all the growth parameters were recorded lowest in $\mathrm{M}_{5}$ (Control). This might be due to the plants grown under plastic mulch experienced higher soil temperature, 
warmer microclimate and weed free environment as compared to straw mulch and control, which resulted in higher growth of plants. Plastic mulches hinder the evaporation and moderate the soil temperature and moisture conditions that helps in better root development and nutrient uptake by plant that ultimately improves the plant growth. The findings of present study are in close agreement with the findings of Khan et al., (2015) in sponge gourd and Bhatt et al., (2011) in summer squash.

Among the varieties, emergence percentage $(81.11 \%)$ and plant height $(122.94 \mathrm{~cm})$ were found to be superior in $V_{2}$ (Surya), while number of leaves per plant (92.20) were recorded maximum in $\mathrm{V}_{1}$ (Arpit). Whereas emergence percentage $(68.66 \%)$, plant height $(118.31 \mathrm{~cm})$ and number of leaves per plant (86.40) in were lowest in $\mathrm{V}_{4}$ (Desi). The difference in growth parameters might be due to the differential capacity to absorb nutrients and difference in photosynthetic efficiency of the different varieties that could be attributed to their genetic makeup. These results are in close conformity with the results obtained by Al-Rawahi et al., (2011) in cucumber and Andino and Motsenbocker (2004) in watermelon.

The interaction effect of mulch materials and varieties showed non- significant results for emergence percentage whereas for plant height and number of leaves per plant, results were significant. Highest emergence percentage (94.44\%) was recorded in $\mathrm{M}_{4} \mathrm{~V}_{2}$ (Transparent Mulch + Surya variety); plant height $(146.02 \mathrm{~cm})$ and number of leaves per plant (113.33) were recorded highest in $\mathrm{M}_{1} \mathrm{~V}_{2}$ (Black Plastic Mulch + Surya variety). These results might be due to the warmer soil microclimate, available moisture, less weed infestation under the plastic mulches than control combined with better genetic potential of Surya variety $\left(\mathrm{V}_{2}\right)$ than others which replicated in to optimum conditions for better plant growth, as stated by of Alenazi et al., (2015) in muskmelon and Andino and Motsenbocker (2004) in watermelon.

Mulching materials had also shown significant results for various yield parameters. $\mathrm{M}_{1}$ (Black Plastic Mulch) took the least number of days taken for first harvesting (41.50 days from sowing) and provided the highest results for number of fruits per plant (37.36), average fruit weight $(95.82 \mathrm{~g})$, yield per plant $(3.58 \mathrm{~kg}$ plant $\left.^{-1}\right)$, yield per hectare $\left(32.36 \mathrm{t} \mathrm{ha}^{-1}\right)$ and number of harvests (17.58) and the inferior results were obtained from the control for all these parameters. The results obtained from present investigation might be due to the effect of improved soil microclimate, weed free environment, low evaporation and higher moisture availability in root zone that helped in better nutrient uptake by plant resulting in early and better vegetative growth which then enhanced the photosynthesis rate and translocation of synthesized food from leaves to fruits, resulted in early harvesting and increased number of fruits per plant under black plastic mulch. These results are in close agreement with findings of Webber et al., (2017) and Bhatt et al., (2011) in summer squash; Khan et al., (2015) in sponge gourd.

Among the varieties $V_{2}$ (Surya) showed the significant results for the yield parameters and took minimum days to first harvesting (43.27 days) and resulted in highest values for no. of fruits per plant (31.13), average fruit weight $(93.70 \mathrm{~g})$, yield per plant $\left(2.94 \mathrm{~kg} \mathrm{plant}^{-1}\right)$, yield per hectare $\left(26.48 \mathrm{t} \mathrm{ha}^{-1}\right)$ and number of harvests (14.80). $\mathrm{V}_{4}$ (Desi) showed the poor performance for all the yield parameters except average fruit weight which was found lowest in $\mathrm{V}_{3}$ (Pratap). These results might be due to the superiority of Surya variety in vegetative growth parameters which contributed to enhance yield parameters subsequently. 
Table.1 Effect of Mulch Materials on Growth and Yield of Summer Squash

\begin{tabular}{|c|c|c|c|c|c|c|c|c|c|c|}
\hline $\begin{array}{l}\text { Mulching } \\
\text { Material }\end{array}$ & $\begin{array}{l}\text { Emergence } \\
\text { Percentage }\end{array}$ & $\begin{array}{c}\text { Plant } \\
\text { Height } \\
\text { (cm) }\end{array}$ & $\begin{array}{c}\text { No. of } \\
\text { Leaves } \\
\text { per } \\
\text { plant }\end{array}$ & $\begin{array}{c}\text { Days } \\
\text { Taken for } \\
\text { First } \\
\text { Harvesting }\end{array}$ & $\begin{array}{c}\text { No. of } \\
\text { Fruits } \\
\text { per } \\
\text { Plant }\end{array}$ & $\begin{array}{c}\text { Average } \\
\text { Fruit } \\
\text { Weight } \\
\text { (g.) }\end{array}$ & $\begin{array}{l}\text { Yield } \\
\text { per } \\
\text { Plant } \\
\text { (kg) }\end{array}$ & $\begin{array}{c}\text { Fruit } \\
\text { Yield } \\
\left(\mathrm{t} \mathrm{ha} \mathbf{a}^{-1}\right)\end{array}$ & $\begin{array}{c}\text { No. of } \\
\text { Harvests }\end{array}$ & $\begin{array}{c}\text { TSS } \\
\left({ }^{0} \mathrm{Brix}\right)\end{array}$ \\
\hline $\mathbf{M}_{1}$ & 79.17 & 138.22 & 100.42 & 41.50 & 37.36 & 95.82 & 3.58 & 32.26 & 17.58 & 3.83 \\
\hline $\mathbf{M}_{2}$ & 72.22 & 135.30 & 90.67 & 42.75 & 32.42 & 94.81 & 3.07 & 27.67 & 15.42 & 3.58 \\
\hline $\mathbf{M}_{3}$ & 68.06 & 105.25 & 79.50 & 49.17 & 25.28 & 85.02 & 2.15 & 19.37 & 11.67 & 3.42 \\
\hline $\mathbf{M}_{4}$ & 83.33 & 129.30 & 96.25 & 42.33 & 28.58 & 93.83 & 2.68 & 24.13 & 13.67 & 3.33 \\
\hline $\mathbf{M}_{5}$ & 61.11 & 98.71 & 76.75 & 51.75 & 23.58 & 81.39 & 1.92 & 17.28 & 10.33 & 2.75 \\
\hline S.E. $\left(\mathrm{m}_{0}\right) \pm$ & 3.20 & 0.75 & 1.21 & 0.69 & 0.25 & 0.42 & 0.02 & 0.15 & 0.22 & 0.21 \\
\hline $\begin{array}{l}\text { C.D. at } \\
5 \%\end{array}$ & 7.49 & 1.75 & 2.84 & 1.61 & 0.58 & 0.98 & 0.04 & 0.35 & 0.52 & 0.48 \\
\hline
\end{tabular}

$\mathrm{M}_{1}$ : Black Plastic Mulch, $\mathrm{M}_{2}$ : Blue Plastic Mulch, $\mathrm{M}_{3}$ : Rice Straw Mulch, $\mathrm{M}_{4}$ : Transparent Mulch, $\mathrm{M}_{5}$ : Control.

Table.2 Effect of Varieties on Growth and Yield of Summer Squash

\begin{tabular}{|c|c|c|c|c|c|c|c|c|c|c|}
\hline Variety & $\begin{array}{l}\text { Emergence } \\
\text { Percentage }\end{array}$ & $\begin{array}{l}\text { Plant } \\
\text { Height } \\
\text { (cm) }\end{array}$ & $\begin{array}{c}\text { No. of } \\
\text { Leaves } \\
\text { per } \\
\text { plant }\end{array}$ & $\begin{array}{c}\text { Days } \\
\text { Taken for } \\
\text { First } \\
\text { Harvesting }\end{array}$ & $\begin{array}{l}\text { No. of } \\
\text { Fruits } \\
\text { per } \\
\text { Plant }\end{array}$ & $\begin{array}{c}\text { Average } \\
\text { Fruit } \\
\text { Weight } \\
\text { (g.) }\end{array}$ & $\begin{array}{l}\text { Yield } \\
\text { per } \\
\text { Plant } \\
(\mathrm{kg})\end{array}$ & $\begin{array}{l}\text { Fruit } \\
\text { Yield } \\
(\mathrm{t} \mathrm{ha} \\
1 \text { ) }\end{array}$ & $\begin{array}{l}\text { No. of } \\
\text { Harvests }\end{array}$ & $\begin{array}{c}\text { TSS } \\
\left({ }^{0} \mathrm{Brix}\right)\end{array}$ \\
\hline$V_{1}$ & 72.22 & 122.02 & 90.20 & 45.80 & 29.40 & 89.81 & 2.66 & 23.92 & 13.73 & 3.33 \\
\hline$V_{2}$ & 81.11 & 122.94 & 89.60 & 43.27 & 31.13 & 93.70 & 2.94 & 26.48 & 14.8 & 3.33 \\
\hline$V_{3}$ & 71.11 & 122.15 & 88.67 & 46.20 & 29.31 & 88.31 & 2.62 & 23.60 & 13.53 & 3.07 \\
\hline$V_{4}$ & 66.68 & 118.31 & 86.40 & 46.73 & 27.93 & 88.88 & 2.51 & 22.57 & 12.87 & 3.80 \\
\hline $\begin{array}{l}\text { S.E. } \\
(\mathrm{m} .) \pm\end{array}$ & 4.06 & 0.50 & 0.74 & 0.66 & 0.19 & 0.37 & 0.02 & 0.18 & 0.22 & 0.21 \\
\hline $\begin{array}{l}\text { C.D. at } \\
5 \%\end{array}$ & 8.33 & 1.02 & 1.52 & 1.36 & 0.40 & 0.76 & 0.04 & 0.36 & 0.44 & 0.44 \\
\hline
\end{tabular}


Table.3 Effect of Mulch Materials and Variety on Growth and Yield of Summer Squash

\begin{tabular}{|c|c|c|c|c|c|c|c|c|c|c|}
\hline Treatment & $\begin{array}{l}\text { Emergence } \\
\text { Percentage }\end{array}$ & $\begin{array}{l}\text { Plant } \\
\text { Height } \\
\text { (cm) }\end{array}$ & $\begin{array}{c}\text { No. of } \\
\text { Leaves } \\
\text { per } \\
\text { plant }\end{array}$ & $\begin{array}{c}\text { Days } \\
\text { Taken for } \\
\text { First } \\
\text { Harvesting }\end{array}$ & $\begin{array}{c}\text { No. of } \\
\text { Fruits } \\
\text { per } \\
\text { Plant }\end{array}$ & $\begin{array}{l}\text { Average } \\
\text { Fruit } \\
\text { Weight } \\
\text { (g.) }\end{array}$ & $\begin{array}{l}\text { Yield } \\
\text { per } \\
\text { Plant } \\
\text { (kg) }\end{array}$ & $\begin{array}{c}\text { Fruit } \\
\text { Yield } \\
\left(t \text { ha }^{-1}\right)\end{array}$ & $\begin{array}{c}\text { No. of } \\
\text { Harvest } \\
\quad s\end{array}$ & $\begin{array}{c}\text { TSS } \\
\left({ }^{0} \mathrm{Brix}\right)\end{array}$ \\
\hline $\mathbf{M}_{1} \mathbf{V}_{1}$ & 77.78 & 136.54 & 95.67 & 42.00 & 36.11 & 94.83 & 3.43 & 30.84 & 17.33 & 3.67 \\
\hline $\mathbf{M}_{1} \mathbf{V}_{2}$ & 88.89 & 146.12 & 113.33 & 40.67 & 40.22 & 98.1 & 3.95 & 35.52 & 19.33 & 4.33 \\
\hline $\mathbf{M}_{1} \mathbf{V}_{3}$ & 72.22 & 136.42 & 98.67 & 41.33 & 37.78 & 96.66 & 3.65 & 32.88 & 17.67 & 2.67 \\
\hline $\mathbf{M}_{1} \mathbf{V}_{4}$ & 77.78 & 133.8 & 94.00 & 42.00 & 35.33 & 93.69 & 3.31 & 29.79 & 16.00 & 4.67 \\
\hline $\mathbf{M}_{2} \mathbf{V}_{1}$ & 72.22 & 134.21 & 90.00 & 42.67 & 31.11 & 93.92 & 2.92 & 26.28 & 15.00 & 2.33 \\
\hline $\mathbf{M}_{2} \mathbf{V}_{2}$ & 77.78 & 140.46 & 101.33 & 41.33 & 34.44 & 97.68 & 3.63 & 30.27 & 16.67 & 3.67 \\
\hline $\mathbf{M}_{2} \mathbf{V}_{3}$ & 72.22 & 135.03 & 83.67 & 44.00 & 32.11 & 93.94 & 3.02 & 27.15 & 15.67 & 4.00 \\
\hline $\mathbf{M}_{2} \mathbf{V}_{4}$ & 66.67 & 131.5 & 87.67 & 43.00 & 32.00 & 93.68 & 3.00 & 26.97 & 14.33 & 4.33 \\
\hline $\mathbf{M}_{3} \mathbf{V}_{1}$ & 66.67 & 109.49 & 82.33 & 49.33 & 26.22 & 85.97 & 2.26 & 20.31 & 12.00 & 4.00 \\
\hline $\mathbf{M}_{3} \mathbf{V}_{2}$ & 77.77 & 102.8 & 68.33 & 46.00 & 26.78 & 89.86 & 2.41 & 21.69 & 12.67 & 2.67 \\
\hline $\mathbf{M}_{3} \mathbf{V}_{3}$ & 66.67 & 110.43 & 96.33 & 49.33 & 25.22 & 79.64 & 2.01 & 18.06 & 11.33 & 3.67 \\
\hline $\mathbf{M}_{3} \mathbf{V}_{4}$ & 61.11 & 98.27 & 71.00 & 52.00 & 22.89 & 84.62 & 1.94 & 17.43 & 10.67 & 3.33 \\
\hline $\mathbf{M}_{4} \mathbf{V}_{1}$ & 83.33 & 131.34 & 102.67 & 43.00 & 29.78 & 90.37 & 2.69 & 24.21 & 13.67 & 4.33 \\
\hline$M_{4} \mathbf{V} 2$ & 94.44 & 125.26 & 93.33 & 41.33 & 29.78 & 98.11 & 2.92 & 26.28 & 14.67 & 3.00 \\
\hline $\mathbf{M}_{4} \mathbf{V}_{3}$ & 83.33 & 131.38 & 90.33 & 43.00 & 28.22 & 92.21 & 2.60 & 23.4 & 13.00 & 2.33 \\
\hline $\mathbf{M}_{4} \mathbf{V}_{4}$ & 72.22 & 129.22 & 98.67 & 42.00 & 26.56 & 94.62 & 2.51 & 22.62 & 13.33 & 3.67 \\
\hline $\mathbf{M}_{5} \mathbf{V}_{1}$ & 61.11 & 98.53 & 80.33 & 52.00 & 23.78 & 83.93 & 1.99 & 17.94 & 10.67 & 2.33 \\
\hline $\mathbf{M}_{5} \mathbf{V}_{2}$ & 66.67 & 100.05 & 71.67 & 47.00 & 24.44 & 84.73 & 2.07 & 18.63 & 10.67 & 3.00 \\
\hline $\mathbf{M}_{5} \mathbf{V}_{3}$ & 61.11 & 97.48 & 74.33 & 53.33 & 23.22 & 79.11 & 1.84 & 16.53 & 10.00 & 2.67 \\
\hline $\mathbf{M}_{5} \mathrm{~V}_{4}$ & 55.56 & 98.76 & 80.67 & 54.67 & 22.89 & 77.79 & 1.78 & 16.02 & 10.00 & 3.00 \\
\hline S.E. (m.) \pm & 6.00 & 0.86 & 1.33 & 1.03 & 0.32 & 0.59 & 0.03 & 0.27 & 0.47 & 0.33 \\
\hline C.D. at5\% & NS & 2.63 & 4.08 & NS & 0.96 & 1.77 & 0.09 & 0.79 & 1.00 & 0.98 \\
\hline
\end{tabular}

Similar observations were recorded by Keerthika et al., (2016) in cucumber; Sithole et al., (2015) in bottle gourd and Ashwini (2014) in snake gourd.

The interaction effect of mulch materials and varieties resulted in non-significant findings for the days taken to first harvesting, while the other yield parameters viz., number of fruits per plant, average fruit weight, yield per plant, yield ha ${ }^{-1}$ and total number of harvests showed significant results. Number of fruits per plant (40.22), yield per plant $(3.95 \mathrm{~kg}$ plant $\left.^{-1}\right)$, yield per hectare $\left(35.52 \mathrm{t} \mathrm{ha}^{-1}\right)$ and total number of harvests (19.33) were found to be best in $\mathrm{M}_{1} \mathrm{~V}_{2}$ (BlackPlastic Mulch +
Surya variety) and the average fruit weight $(98.11 \mathrm{~g})$ was maximum in $\mathrm{M}_{4} \mathrm{~V}_{2}$ (Transparent Mulch + Surya variety) followed by $\mathrm{M}_{1} \mathrm{~V}_{2}$ (Black Plastic Mulch + Surya variety) $(98.10 \mathrm{~g})$. All these parameters showed the inferior results in $\mathrm{M}_{5} \mathrm{~V}_{4}$ (Control + Desi variety). Increase in vegetative growth of plant associated with increased rate of photosynthesis activity had a great impact on yield per plant. Similar observations were also recorded by Alenazi et al., (2015) and Ekinci and Dursun (2009) in melon. Mulch materials, varieties and their interaction showed the significant results for total soluble solids (TSS). Among the mulch materials $\mathrm{M}_{1}$ (Black Plastic Mulch) $\left(3.83^{0}\right.$ Brix), among the 
varieties $\mathrm{V}_{4}$ (Desi) $\left(3.80^{\circ}\right.$ Brix) and among interaction $\mathrm{M}_{1} \mathrm{~V}_{4}$ (Black Plastic Mulch + Desi Variety) $\left(4.67^{0}\right.$ Brix) resulted in highest TSS content. These results are close confirmation with the findings of Parmar et al., (2013) in watermelon; Ekinci and Dursun (2009) and Deoraoji and Chandrashekhar (2003) in musk melon.

From the present results it can be concluded that plastic mulches have positive effects on growth and yield in summer squash where black plastichas more pronounced effects in comparison to other mulch materials so can be recommended on commercial basis in the region where study was conducted (Doaba region of Punjab). Among varieties, Surya variety with its better performance than other varieties can be suggested for commercial cultivation. Hence for enhancing commercial cultivation of summer squash with better yield and quality 'Surya' variety should be grown under black plastic mulch.

\section{References}

Alenazi, M., Abdel-Razzak, H., Ibrahim, A., Wahb-Allah, M. and Alsadon, A. 2015. Response of muskmelon cultivars to plastic mulch and irrigation regimes under greenhouse conditions. J. Anim. Plant Sci. 25(5): 1398-1410.

Al-Rawahi, M., Al-Said, F.A., Khan, I.A. and Al-Khanjary, S. 2011. Diversity of cucumber accessions in Oman. Int. J. Environ. Agric. Res. 13(4): 505-510.

Andino, J.R. and Motsenbocker, C.E. 2004. Colored plastic mulches influence cucumber beetle population s, vine growth, and yield of watermelon.HortScience.39 (6): 124649.

Anonymous. 2011. www.ncpahindia.com Anonymous. 2016. http://www.fao.org/faostat/en/\#home
Ashwini, K. 2014. Studies on the performance of F1 hybrids and their parents in snake gourd (Trichosanthes anguina L.) for yield and yield attributing characters. http://

krishikosh.egranth.ac.in/handle/1/69482

Bhatt, L., Rana, R., Uniyal, S.P. and Singh, V.P. 2011. Effect of mulch materials on vegetative characters, yield and economics of summer squash (Cucurbita pepo) under rainfed mid hill condition of Uttarakhand. Vegetable Science. 38(2): 165-168.

Bobby, A., Prashanth, P., Seenivasan, N. and Mishra, P. 2017. Effect of Different Mulch Materials on Weed Control in Cucumber (Cucumis sativus L.) Hybrid "Multistar" Under Shade Net Conditions. Int. J. Pure Appl. Biosci. 5(5): 1246-1251.

Coolong, T. 2010. Performance of paper mulches using a mechanical plastic layer and water wheel transplanter for the production of summer squash. HortTechnology. 20(2): 319-324.

Coolong, T. 2012. Mulches for Weed Management in Vegetable Production, Weed Control, Dr. Andrew Price (Ed.). pp. 57-73.

Dhaliwal, M.S. 2012. Handbook of Vegetable Crops. 2nd revised edition. New Delhi: Kalyani Publishers. P 116-17.

Ekinci, M. and Dursun, A. 2009. Effects of different mulch materials on plant Growth, some quality parameters and yield in Melon (Cucumis melo L.) Cultivars in high altitude environmental condition. Pak J Bot. 41(4): 1891-1901.

Gomez, L.A. and Gomez, A.A. 1984. Statistical procedure for agricultural research. $3^{\text {rd }}$ edition. Singapore: John Wiley and Sons. $680 \mathrm{p}$.

Gordon, G.G., Foshee, W.G., Reed, S.T., Brown, J.E., Vinson, E. and Woods, F.M. 2008. Plastic Mulches and Row 
Covers on Growth and Production of Summer Squash. Int. J.Veg. Sci. 14(4): 322-338.

Keerthika, T., Devaki, C.S., Suma, F. and Urooj, A. 2016. Studies on the nutritional and quality characteristics of Cucumis sativus varieties. Agric. Sci. Res. J. 6(4): 79-85.

Khan, S., Pal, M. and Kumar, V. 2015. Influence of different mulches on growth and yield of sponge gourd (Luffa clyndrica L.). Plant Archives. 15(1): 393-395.

Mahadeen A.Y. 2014. Effect of polyethylene black plastic mulch on growth and yield of two summer vegetable crops under rain-fed conditions under semi-arid region conditions. Amer. J. Agric. Biol. Sci. 9(2): 202-207.

Parmar, H.N., Polara, N.D. and Viradiya, R.R. 2013. Effect of mulching material on growth, yield and quality of watermelon (Citrullus lanatus thunb) cv. Kiran. Univers. J. Agric. Res. 1(2): 30-37.

Patil, S.S., Kelkar, T.S. and Bhalerao, S.A. 2013. Mulching: A soil and water conservation practice. Res. J. Agric. Forest. Sci. 1(3): 26-29.

Sarhan, T.Z., Mohammed, G.H. and Teli, J.A. 2011. Effect of bio and organic fertilizers on growth, yield and fruit quality of summer squash. Sarhad J. Agric. 27(3): 377-383.

Sithole, N.J., Modi, A.T. and Mabhaudhi, T. 2015. Seed quality of selected bottle gourd landraces compared with popular cucurbits. S. Afr. J. Plant \& Soil. 33(2): 133-139.

Webber, C.L., White Jr, P.M., Spaunhorst, D.J. and Petrie, E.C. 2017. Comparative Performance of Sugarcane Bagasse and Black Polyethylene as Mulch for Squash (Cucurbita pepo L.) Production. J. Agric. Sci. 9(11): 1-9.

\section{How to cite this article:}

Dinesh Kumar and Rishu Sharma. 2018. Effect of Mulching on Growth, Yield and Quality in Different Varieties of Summer Squash (Cucurbita pepo L.). Int.J.Curr.Microbiol.App.Sci. 7(06): 2113-2119. doi: https://doi.org/10.20546/ijcmas.2018.706.251 